INDEPENDENT JOURNAL OF MANAGEMENT \& PRODUCTION (IJM\&P)

http://www.ijmp.jor.br

v. 12, n. 5, July-August 2021

ISSN: 2236-269X

DOI: 10.14807/ijmp.v12i5.1435

\title{
THE INFLUENCE OF THE GOVERNANCE AND INNOVATION INDEXES ON THE ENVIRONMENTAL PERFORMANCE OF COUNTRIES
}

\author{
Ronaldo Leão de Miranda \\ Universidade Regional de Blumenau - FURB, Brazil \\ E-mail: ronaldo_leaomiranda@hotmail.com \\ Alberto Augusto Lange \\ Universidade Regional de Blumenau - FURB, Brazil \\ E-mail:aa_lange@hotmail.com \\ Adriana Kroenke \\ Universidade Regional de Blumenau - FURB, Brazil \\ E-mail: akroenke@furb.br \\ Iara Regina dos Santos Parisotto \\ Universidade Regional de Blumenau - FURB, Brazil \\ E-mail: iaraparisotto@furb.br
}

Submission: $8 / 25 / 2020$

Revision: 9/16/2020

Accept: 9/29/2020

\section{ABSTRACT}

In a period marked by ascending international independence and integration, governance and innovation are considered important tools in the sustainable growing process of countries, highlighting a constant search for positive development. The present paper intends to analyze the influence of the innovation and governance indexes on the environmental performance of nations around the globe. This is a descriptive study, we chose a quantitative approach and the data were collected on the Worldwide Governance Indicators (2018), Global Innovation Index (2018) and Environmental Performance Index (2018) websites. Subsequently, the data were organized and tabulated on the software SPSS $^{\circledR}$, version 22. Our analysis happened with the aid of descriptive statistics and linear regression. The main results indicate that countries do not show better environmental performance - where we take environmental health and the vitality of the ecosystems into consideration - due to the confidence and respect to the process in which governments are elected and observed. In the innovation perspective and context, we could infer that it influences the environmental performance among the 108 countries that compose the sample. 
INDEPENDENT JOURNAL OF MANAGEMENT \& PRODUCTION (IJM\&P)

http://www.ijmp.jor.br

v. 12, n. 5, July-August 2021

ISSN: 2236-269X

DOI: 10.14807/ijmp.v12i5.1435

Therefore, the opinion regarding the importance of innovation is essential to comprehend the development of countries, and that includes the environmental field.

Keywords: Governance. Innovation. Environmental Performance. Nations. Indexes.

\section{INTRODUCTION}

Since the late 1960s, a new feeling has arisen among societies, promoting interdependence from international communities, creating opportunities for the governance field to improve, bringing new positive techniques in the global context of the nation. In this paper, the term global governance is used to denote it beyond one unique state, county, or geographical division. Considering this, contemporary society traces its trajectory searching for sustainable, safe, and lasting development.

By the same token, public policies must then promote the sustainable growth and development of nations, however, that is a challenge (Lundvall, 2007; Freeman, 2002). Another key point related to this context is that the human evolution has brought with itself the necessity of optimization of the available resources, modernizing the manners of how policies are made, or simply, taking the role of the state to a new and superior level in relation to sustainable management (Insead, 2018).

This scenario implies in the reflection of the concept of global governance. It focuses on constant enhancements, having as a core task the form as how power is executed while the state is managed, maintaining a sustainable development (World Bank, 2017). This institutional characteristic is stressed and built through the relationship with the other existing classes, which act as complementary actors in the innovation process (Bresser-Pereira, 2007).

In a period of a prominent flourishing of international integration and interdependence, governance and innovation are considered strong conductors towards the evolution and performance of nations (Freeman, 1989; Lundvall, 2007). In this case, innovation in the words of Schumpeter (1997) and Porter (1999), is constituted as an indispensable element for the development of the country. As a result of growth and development the crescent focus is the creation of a continuing sustainable society.

Moreover, we can point out that since environmental issues showed up and were emphasized in the last three decades, the state has been an active performer trying to solve them (Fiorino, 2011). A few recent studies highlight the scales that the global, regional, and local governances are becoming more committed about regulating environmental issues (Chow, Kopp \& Portney, 2003), however, the State-Nation is yet central, with a long term orientation (Fiorino, 2011). 
DOI: 10.14807/ijmp.v12i5.1435

In the economic field, countries are normally compared using popular indexes such as the Gross Domestic Product, Unemployment Rates, Trade Balance, among others. Consequently, the closest point ever reached in respect to environmental performance, formulating indexes in the area, has been done by the universities of Yale \& Columbia.

The result is the worldwide known Environmental Performance Index (EPI), which tries to measure the performance of public policies regarding the environmental field, analyzing how countries tend to respond to issues in this area (Toigo \& De Mattos, 2016). The index prioritizes two main goals: reducing the environmental harm to human health, as well as promoting the vitality of ecosystems, requiring countries good management of the available natural resources.

Therefore, considering this context, the objective of this study is to analyze the influence of global governance and innovation in the environmental performance of countries. The justification in developing a study with these three indicators is in the explanation, whether there is or not, the influence of the governance of the country, and also the innovation setting of the country in its environmental performance.

Likewise, we contribute to current discussions in this field, expanding the present literature in regard to this topic. Similarly, the practical contribution emphasizes and reinforces the importance given to these three concepts throughout the years, mainly by public and private governors in their decision-making process. The results of this influence indicate how nations are behaving towards their environmental performance, also considering their innovation and governance structures.

The social contribution of this paper is connected to a civic duty, which is showing the awareness given by the academy to these fields, considering innovation, the environment and governance settings, fundamental subjects that deserve attention. In addition, we understand that new perceptions and insights are also required. This paper is divided in six different sections: this introduction, a theoretical background, methodology, results, and discussions, and at last, closing remarks.

\section{THEORETICAL BACKGROUND}

This section contemplates concepts and focuses presented by authors related to the governance, innovation, and environmental performance literature, gathering a valuable background to support our findings. 
DOI: 10.14807/ijmp.v12i5.1435

\subsection{Global Governance and Innovation Lighten by the Theory of Institutions}

Global governance is understood as a managerial model brought to the public environment, that through dialogue, is formed by permanent negotiations, as well as a strategic decision-making process, typically trying to agree with the force of the law and wisely applying resources, resulting in an effective structure (Sampson, 2008). From this perspective, global governances have become notoriously comprehended as a subject of debates, serving as foundations for reflections related to measurements in the human rights field, democratic movements, or quality in respect to public management efficiency (Yong \& Wenhao, 2012).

These same metrics started to be presented with the Worldwide Governance Indicator (WGI), created and introduced in the 1990s, working with six major aspects regarding the state behavior and action: fiscal responsability and representativeness, political stability and absence of terrorism or violence, governmental efficiency, regulatory quality, the force of the law, and at last, the control of corruption (Kaufmann, Kray \& Mastruzzi, 2009).

In this case, the theory of institutions may help us highlighting that global governance is a result of institutionalized patterns, these might be, for instance, an open dialogue that congregates a huge part of international actors, reinforcing the role of the governances, pursuing arguments for the full development of a society (Carvalho et al., 2005). According to Kaufmann et al. (2009), the Worldwide Governance Index evoked during the first decade of the XXI century a few necessary changes, as well as the index implementation. This tends to shield the civil society, which will believe in the goodwill of the state through its democratic process.

This global governance conception summarizes the comprehension towards the evolution how countries are actually managed, bringing the entire society, as well as other representative sectors to the decision-making process, decentralizing the power, shaping a more equitable nation, with a fair system, and also transparent (Casady, Eriksoon \& Levitt, 2020).

This ongoing political environment, highly globalized among nations, requires knowledge and efficient strategies to formulate profitable policies, either for the public itself or for the whole society. With that being said, the institutionalization of good practices and the establishment of a solid global governance structure that provides and eases innovation is essential, aside from recognizing and respecting limits settled by this same governance at a supranational level.

Albeit there is not a consensus in the literature related to the definition of innovation, Freeman (1987) points out a compatible argument that matches with the one present in this 
INDEPENDENT JOURNAL OF MANAGEMENT \& PRODUCTION (IJM\&P)

http://www.ijmp.jor.br

v. 12, n. 5, July-August 2021

ISSN: 2236-269X

DOI: 10.14807/ijmp.v12i5.1435

paper, proposing innovation not only as of the individual labor in companies, but also the collective effort that governments and institutions perform their functions, enabling the generation of innovation in a national economy. According to Senna, Campos \& Silva (2017), innovation in the environmental field represents a cluster of varied factors, which might include firms into a nation, due to their enough technological capabilities they can then embrace every environmental concept in their production processes.

In the words of Ezell, Nager and Atkinson (2016), a good national innovation system offers sufficient resources, which can be financial, political (as incentives), or even with efficient institutions. Altogether, we have a combination that benefits the development of innovation as a whole.

So we can comprehend innovation as the main element, which guides public policies redirected to a more dynamic economic environment, bolstering growth in its entirety (Arbix et al., 2010). Thus, nations that choose the capitalist ideology tend to have in innovation the hope to keep their states competitive in a globalized market, where the liberalism logic and the free market reigns with constant technological and legal events, frequently testing the current governance structure (Verde, 2018).

This innovation conception turned out to be a subject of discussion among various hegemonies around the world. In this field, their troubles might not be briefly solved, however, in the long-term a sustainable economic development tends to stand out (Insead, 2018), guiding the management process, offering positive insights during the decision making and the strategy implementation. In such cases, the government serves as a facilitator implementing innovation policies at a national level. Yu, Ramanathan and Nath (2017) point out that initiatives of innovation that come from organizations, either public or private, could help in the national level when it is related to sustainable development in the current political and marketing scenarios.

The next subsection contemplates a theoretical review of concepts related to the environmental performance of nations, connecting global governance and innovation.

\subsection{The Environmental Performance of Nations}

In the last two decades, many analyses related to the protection of nature were made considering the environmental performance of countries as well (Fiorino, 2011). Since environmental issues showed up and were emphasized in the last three decades, the state has been an active performer trying to solve them (Fiorino, 2011). A few recent studies highlight 
INDEPENDENT JOURNAL OF MANAGEMENT \& PRODUCTION (IJM\&P)

http://www.ijmp.jor.br

v. 12, n. 5, July-August 2021

ISSN: 2236-269X

DOI: 10.14807/ijmp.v12i5.1435

the scales that the global, regional, and local governances are becoming more committed to regulating environmental issues (Chow, Kopp \& Portney, 2003).

In addition to this context, we do have other environmental adversities around the world, as they are modern realities. Considering this fact, institutionalized nations perform a fundamental role when they behave against these issues, as Garcia and Moreno (2018) highlight while mentioning, for example, the Environment Action Programme in Europe, where we may find two main conditions regarding public decision-making: a) Protection and conservation of natural capital, and, b) To transform the entire European block as a self-sufficient user in relation to natural resources, becoming more competitive and ecologic. This is certainly a good representation of how contemporaneity requires a friendly approach to the present environment situation (Fiorino, 2011).

The regular comparison made when countries are analyzed includes indexes such as the GDP, Unemployment Rates, the Commercial Balance, Investments, among others. In the other way around these comparisons, we may find the Environmental Performance Index (EPI), created and constantly used by universities around the world, especially Yale \& Columbia. The EPI measures the conduct taken by public policies in regard to the environmental issue, these analyses tend to be vital to public governance (Toigo \& De Mattos, 2016). After the approval of both indexes, two main goals are achieved: mitigating the environmental impacts, offering a more humane condition, and also, motivating the entire society towards better use of the natural resources, preserving in an institutional way the vitality of the ecosystems (EPI, 2018).

We can agree that there is a simultaneity between the indicators and all recent measures taken during world conferences, becoming responsible for reactions that provoke changes in relation to the current environmental scenario, for instance, we can cite the Rio+20 Conference, or, the Sustainable Development Goals, developed by the United Nations. Kournetas and Zervopoulos (2019) also call attention to the positive influence caused by the Kyoto Protocol, signed in the end of the XX century, and that took place in 2005, shaping public policies positively among globalized nations. Consequently, it is notable that the environmental performance is nowadays a popular and crucial character while countries seek innovation, presenting itself as a change factor, supporting the human capital during this journey at the same time that the modern thought among societies includes an ecologic way of thinking (Gölgeci et al., 2019).

According to Marques (2018), this innovation context, as well as positive governance, has the necessary strength to influence the environmental performance path in this globalized, modern, and wild world that we live in. It is therefore clear that the present-day society is living 
INDEPENDENT JOURNAL OF MANAGEMENT \& PRODUCTION (IJM\&P)

http://www.ijmp.jor.br

v. 12, n. 5, July-August 2021

ISSN: 2236-269X

DOI: 10.14807/ijmp.v12i5.1435

the reality expected by the environmental performance index. This scenario contemplates a great value of information, democracy, and data, which are ways of evaluating governance throughout the globe. Governments normally perform seeking for acceptance, with that being said, this context will be determinant as we analyze their own acts. The success and the failure rates are easily identified with the help of modern indexes, whether they are social, political or economic, but in this environmental background, it is totally comprehensible that it has a major relevance, deserving crucial attention by modern institutions (Wendling et al.,2018).

\section{METHODOLOGY}

This study is categorized as descriptive in regard to its objective, and the procedures present a study accomplished using secondary data. The research was also carried out with a quantitative approach. The data used in this work were collected on the indicators sources, being the Worldwide Governance Indicator (2018), the Global Innovation Index (2018) and at last, the Environmental Performance Index (2018). The data gathering happened from January to February, 2020.

The Worldwide Governance Indicator, according to Kaufmann, Kray and Mastruzzi (2011) is composed by three main perspectives: a) The process how governments are elected, monitored and substituted; b) The capacity of the government in relation to efficient and solid policies, which are then implemented; and, c) The perceived respect on part of citizens and the state towards institutions that regulate economic and social interactions that exist among them. The authors assembled two governance measures to each of these three perspectives, resulting in a total of six dimensions of governance, defined as follow:

A- The process of how governments are elected, monitored, and replaced:

a.1 - Voice and Responsibility: It captures the perceptions of how much citizens are capable to participate in the country's election process, as well as freedom of expression, association, and free press.

a.2 - Political Stability and Absence of Violence and Terrorism: It catches the probability of governments being destabilized or taken down through unconstitutional or violent manners, including violence and terrorism politically motivated.

B - Capacity of governments to effectively formulate and apply solid policies:

b.1 - Government Efficacy: Perceptions regarding the quality of public services are constantly analyzed. Also, the quality of the public function and independence degree related to public pressure. We must also consider the quality of creation and application, as well as the credibility of the government with these exact policies. 
DOI: 10.14807/ijmp.v12i5.1435

b.2 - Regulatory Quality: This is related to the ability of the government to formulate and apply policies and solid regulations; they tend to allow better development of the private sector.

C - The respect given by citizens and the state to institutions that rule economic interactions, as well as social ones that exist among them:

c.1 - Constitutional State: It gathers perceptions about the limits related to how agents trust and respect the rules of the society, and in particular the quality of how contracts are made and maintained, property rights, the law enforcement, as well as probabilities related to crime and violence.

c. 2 - Corruption Control: This dimension is related to the limit where public power can reach in regard to private profits, including tiny and huge amounts of corruption, as well as extractions of the state by elites and private interests.

The Global Innovation Index (GII) utilizes 80 different indicators to calculate four innovation segments: a) The Innovation Input; b) The Products of Innovation; c) The general result of the GII (the average outcome of the previous two sub-items) and d) The Innovation Efficiency, which represents a wise administration related to investments made (GII, 2018). Figure 1 presents both items and sub-items of the Global Innovation Index.

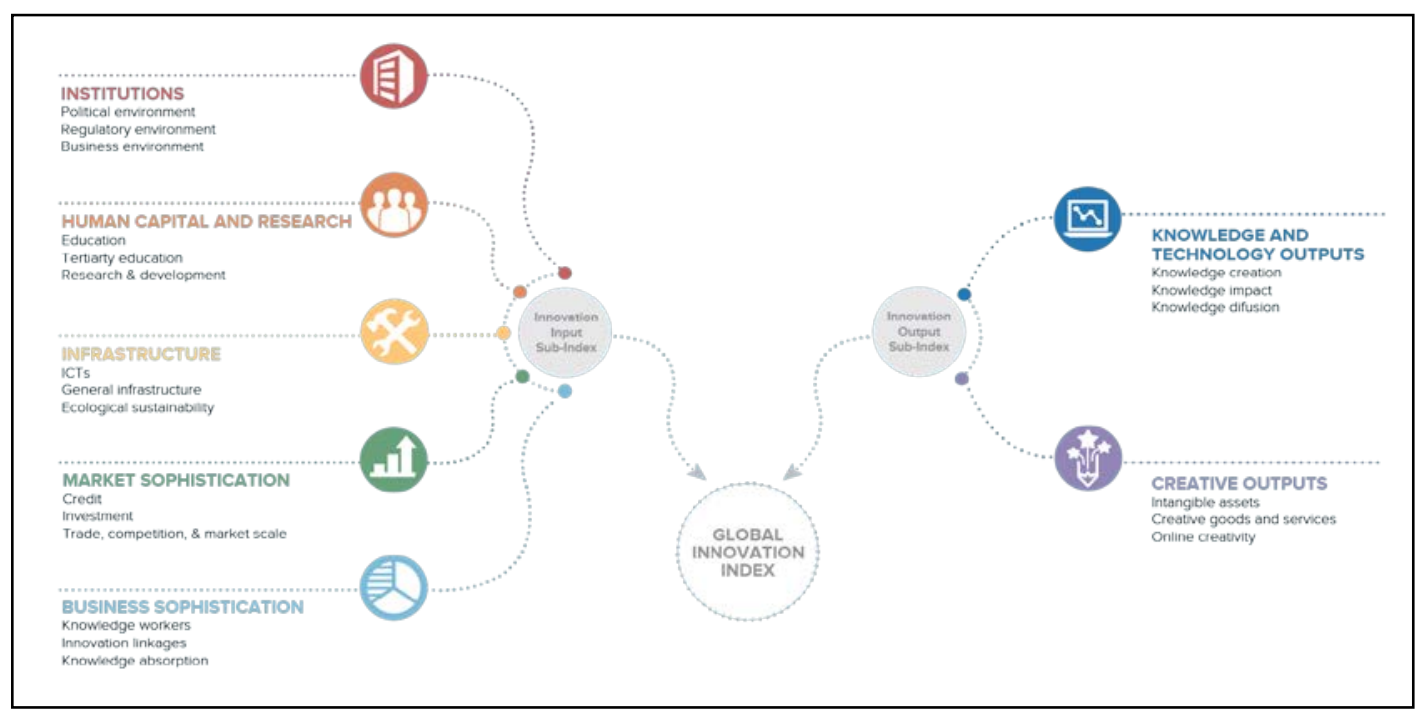

Figure 1: Global innovation index, sub-items, pillars and indicators Source: Global Innovation Index (2019).

Every innovation indicator is a metric derived from aggregation methods, which come from a group of components that integrate, mainly, knowledge and productivity of a country, and these factors are indeed essential to stimulate the economy, and also the social welfare. Thus, when a country partakes on the GII, its result depends exclusively on the economic level, 
DOI: 10.14807/ijmp.v12i5.1435

all the investments made in research, the legitimacy of the government, among other factors (Grupp \& Schubert, 2010; Hoelscher \& Schumbert, 2015; Oecd, 2005).

Now, regarding the Environmental Performance Index - EPI, we may find meticulous analysis, since this indicator classifies countries in 24 aspects of development, subdivided into ten different categories that intend to guarantee the environmental health and the vitality of the ecosystems. This is important since these metrics can provide the academic and social communities considerable information about how close to its environmental goals the country really is. Therefore, the EPI is going to offer a type of scorecard, this worthwhile information highlights the performance of governments and governors around the world, exposing good insights with the best practices, guiding other countries in the direction of sustainable development (Toigo \& De Mattos, 2016).

However, by the same token, the EPI reveals a tension between two crucial dimensions of the sustainable development: (1) Environmental health, which rises with economic growth and prosperity, and (2) The vitality of the ecosystems, that is under pressure due to industrialization and urbanization processes. The good governance context is then a critical factor, which may balance both dimensions and set them in the direction of sustainability. Figure 2 illustrates the composition of each of these described dimensions.

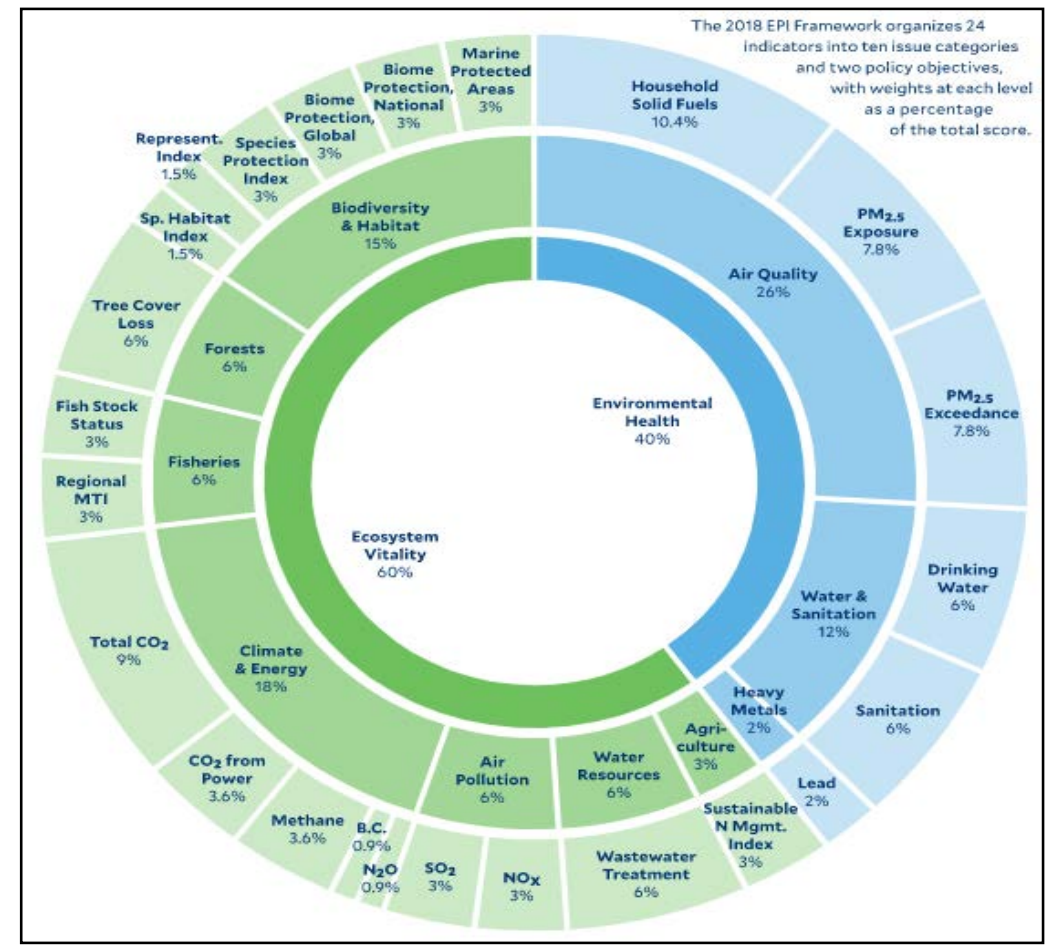

Figure 2: The environmental performance index and its dimensions and sub-dimensions Source: Environmental Performance Index (2018) 
INDEPENDENT JOURNAL OF MANAGEMENT \& PRODUCTION (IJM\&P)

http://www.ijmp.jor.br

v. 12, n. 5, July-August 2021

ISSN: 2236-269X

DOI: 10.14807/ijmp.v12i5.1435

The control variables in this study are the Human Capital and Global Gross Domestic Product (GDP). These two variables were chosen due to the impact caused in the final result of the Worldwide Governance Index, Global Innovation Index, and Environmental Performance Index of each country.

According to the World Bank (2020), Human Capital is a vital factor to sustainable and inclusive economic growth, measured in each country accordingly to its available structure to the civil society (Health and Education accesses are relevant examples). On the other hand, the global Gross Domestic Product is measured and calculated by the World Bank as a value reached by globalized markets, considering all the goods and services transacted in a country during a specific year.

The consolidated sample contemplates 108 countries since these were the ones that had official data in all three indexes used in this research. In the following board (1), we have the countries that compose the sample.

Board 1: List of countries that compose the sample

\begin{tabular}{|c|c|c|c|c|c|c|}
\hline Albania & Algeria & Argentina & Armenia & Australia & Austria & Azerbaijan \\
\hline Bangladesh & Belgium & Bolivia & Botsuana & Brazil & Brunei & Darussalam \\
\hline Bulgaria & $\begin{array}{l}\text { Burkina } \\
\text { Faso }\end{array}$ & Cameroon & Canada & Chile & China & Colombia \\
\hline Costa Rica & Ivory Coast & Croatia & Cyprus & $\begin{array}{c}\text { Czech } \\
\text { Republic }\end{array}$ & Denmark & $\begin{array}{c}\text { Dominican } \\
\text { Republic }\end{array}$ \\
\hline Equador & Egypt & El Salvador & Estonia & Ethiopia & Finland & France \\
\hline Germany & Greece & Guatemala & Guinea & Honduras & Hungary & Iceland \\
\hline India & Indonesia & Ireland & Israel & Italy & Jamaica & Japan \\
\hline Jordan & Kazakhstan & Kenya & $\begin{array}{l}\text { South } \\
\text { Korea }\end{array}$ & Kuwait & Latvia & Lebanon \\
\hline Lithuania & Luxembourg & Madagascar & $\begin{array}{l}\text { Republic } \\
\text { of Malawi }\end{array}$ & Malaysia & Mali & Malta \\
\hline Mexico & $\begin{array}{l}\text { Republic of } \\
\text { Moldova }\end{array}$ & Mongolia & Morocco & Mozambique & Namibia & Netherlands \\
\hline $\begin{array}{c}\text { New } \\
\text { Zealand }\end{array}$ & Niger & Nigeria & Norway & Oman & Pakistan & Panama \\
\hline Paraguay & Peru & Philippines & Poland & Portugal & Qatar & Romenia \\
\hline Russia & $\begin{array}{l}\text { Saudi } \\
\text { Arabia }\end{array}$ & Senegal & Serbia & Singapore & Slovenia & Spain \\
\hline Sri Lanka & Sweden & Switzerland & Taiwan & Tanzania & Thailand & $\begin{array}{c}\text { Trinidad and } \\
\text { Tobago }\end{array}$ \\
\hline Tunisia & $\begin{array}{c}\text { United Arab } \\
\text { Emirates }\end{array}$ & Uganda & Ukraine & $\begin{array}{l}\text { United } \\
\text { Kingdom }\end{array}$ & $\begin{array}{c}\text { United } \\
\text { States of } \\
\text { America }\end{array}$ & Uruguay \\
\hline Vietnam & Zambia & Zimbabwe & & & & \\
\hline
\end{tabular}

Subsequently, the data were organized and tabulated on the software SPSS ${ }^{\circledR}$, version 22. The analysis of the data happened with descriptive statistics, and also, with linear regression. In the words of Hair et al. (2009), this paradigm allows us to verify and recognize the influence and relation among the variables of the statistical model. The following equation 
DOI: 10.14807/ijmp.v12i5.1435

represents the relation between the dependent variable with the independent variable chosen in the described model.

Equation 1: $\mathbf{E P I}_{i t}=\beta_{0}+\beta_{1} \mathrm{WGI}_{i t}+\beta_{2} \mathrm{GII}_{i t}+\beta_{3}$ Human Capital $+\beta_{4}$ Global GDP $+\varepsilon$

We used the scores already available on the sources, and since they are divided into scales that go from 0 to 100 , no standardization was required. In the following section, we present the results, as well as our discussions related to the context.

\section{RESULTS AND DISCUSSION}

We investigated via statistical calculations, whether the governance and global innovation may influence the environmental performance of the countries or not. The following table (1), presents the average result, pattern deviation, and the number of countries analyzed.

Table 1: Descriptive statistics

\begin{tabular}{|c|c|c|c|c|c|}
\hline Variables & Minimum & Maximum & Average & $\begin{array}{c}\text { Pattern } \\
\text { Deviation }\end{array}$ & $\mathbf{N}$ \\
\hline $\begin{array}{l}\text { WGI - Worlwide Governance } \\
\text { Index }\end{array}$ & 25,12 & 94,91 & 60,04 & 16,21 & 108 \\
\hline $\begin{array}{l}\text { GII - Global Innovation Index } \\
\text { EPI - Environmental }\end{array}$ & 17,41 & 67,69 & 38,39 & 12,23 & 108 \\
\hline Performance Index & 29,56 & 87,42 & 61,14 & 12,55 & 108 \\
\hline $\begin{array}{c}\text { C1 - Human Capital - HC } \\
\text { C2 - Global GDP }\end{array}$ & 32 & 88 & 60,73 & 14,47 & 108 \\
\hline GDPG & 7064971176 & $2,22133 \mathrm{E}+13$ & $8,93930 \mathrm{E}+11$ & $2,8584 \mathrm{E}+12$ & 108 \\
\hline
\end{tabular}

In the first column of the previous table, we present our variables WGI, GII, EPI, HC and Global GDP. Also, there are the results related to the minimum and maximum of the included variables (except the Global GDP, which is categorized as currency, US\$), since they are calculated in a scale that goes from 0 to 100. In the fourth column, we may find the average of the studied variables, already realizing that the one with the lowest result is the GII, which therefore means that the entirety of the sample combined has a low innovation rate compared to the other two variables (WGI and EPI). In the fifth and sixth columns, we can find the pattern deviation of the observed countries, consequently, we notice that none of the 108 countries has an average close to 100, limit of the score. In table 2 we can find the summary and the results of the model. 
INDEPENDENT JOURNAL OF MANAGEMENT \& PRODUCTION (IJM\&P)

http://www.ijmp.jor.br

v. 12, n. 5, July-August 2021

ISSN: 2236-269X

DOI: 10.14807/ijmp.v12i5.1435

Table 2: Summary and results of the model

\begin{tabular}{|c|c|c|c|c|c|}
\hline \multirow{2}{*}{ Model } & \multicolumn{2}{|c|}{$\begin{array}{l}\text { Non-Standardized } \\
\text { Coefficients }\end{array}$} & \multirow{2}{*}{$\begin{array}{c}\begin{array}{c}\text { Standardized } \\
\text { Coefficients }\end{array} \\
\text { Beta }\end{array}$} & \multirow{2}{*}{$T$} & \multirow{2}{*}{ Sig. } \\
\hline & B & $\begin{array}{c}\text { Standardized } \\
\text { Error }\end{array}$ & & & \\
\hline Constant & 24,926 & 3,812 & & 6,539 & 0,000 \\
\hline $\begin{array}{l}\text { WGI - Worlwide } \\
\text { Governance Index }\end{array}$ & - 2,903 & 4,350 & $-0,037$ & - 0,667 & 0,506 \\
\hline $\begin{array}{c}\text { GII - Global Innovation } \\
\text { Index }\end{array}$ & 0,666 & 0,121 & 0,649 & 5,486 & 0,000 \\
\hline C1 - Humane Capital - HC & 21,274 & 9,700 & 0,245 & 2,193 & 0,031 \\
\hline $\begin{array}{c}\text { C2 - Worldwide GDP - } \\
\text { GDPM }\end{array}$ & $-6,004 \mathrm{E}-13$ & 0,000 & $-0,136$ & $-2,236$ & 0,027 \\
\hline \multirow[t]{2}{*}{ Summary of the model } & $\mathbf{R}$ & $\mathbf{R}^{2}$ & $\begin{array}{c}\mathbf{R}^{2} \\
\text { Adjusted }\end{array}$ & DW & Anova \\
\hline &, $830^{\mathrm{a}}$ & ,689 & ,677 & 1,957 & 0,000 \\
\hline
\end{tabular}

Note - Dependent variable: Environment Performance Index - EPI. Predictors: (Constant) Worldwide

Governance Index, Global Innovation Index, Human Capital and Global GDP. DW = Durbin-Watson

Source: Research data (2020).

Initially, we can observe that the correlation coefficient represented by $\mathrm{R}$ has a value of 0,830 , on the other hand, the $\mathrm{R}^{2}$ (explicative power of the model), reached a value of 0,689 . With that being said, we can conclude that the WGI, the GII, the Global GDP, and the Human Capital variables explain 69\% of the EPI (Environmental Performance Index). In regards to the Durbin-Watson test, we shall reinforce that it is one of the requirements to fulfill the linear regression pattern, and in this case, certifying that there is not an autocorrelation among the residues (the difference between expected and reached value).

Accordingly, our Durbin-Watson reached a final result of 1,957, close to 2, which in the words of Hair et al (2009), is a respected value, attesting that this autocorrelation might not exist in the researched model. In regard to the ANOVA analysis, we can notice significance in the linear regression process.

This characteristic could also be found in the control variables (Global GDP and Human Capital), both presenting significances. This shall indicate that besides of innovation, macroeconomic aspects significantly influence the environmental performance of countries. In this relation, we could observe that the EPI rises while the Global GDP is reduced among the countries.

It turns out to be a contradictory result, since a few nations of the sample are not considered rich, and they even demonstrate a high amount of degradation related to natural resources. Many possibilities come up in this scenario, one of them can be a low level of 
INDEPENDENT JOURNAL OF MANAGEMENT \& PRODUCTION (IJM\&P)

http://www.ijmp.jor.br

v. 12, n. 5, July-August 2021

ISSN: 2236-269X

DOI: 10.14807/ijmp.v12i5.1435

rubbish treatment due to the lack of financial resources, which consequently, contaminates rivers, the soil, the air people breath, among other conditions that downgrade human life.

Considering these results presented in the previous table, we move forward to an analyses and theoretical discussion. It is notable that the only non-significant variable attained was the WGI $(<0,05)$. Thus, it is not possible to assure that the Worldwide Governance Index (WGI) influences the Environmental Performance Index (EPI) of the analyzed sample. In view of this result, it might not be possible to infer that while more individuals trust and respect the democratic process where governments are elected, monitored and substituted; the capacity of the government to effectively formulate and apply solid policies; and also the respect of citizens and the state in relation to the institutions that facilitate economic and social interactions; does not make these countries better in the Environmental Performance Index, since it has the environmental health and the ecosystem vitality as main goals (Kaufmann, Kray \& Mastruzzi, 2011; Toigo \& De Mattos, 2016). As long as these results continue to be studied and to be measured, we can confirm that, by now, the global governance does not influence the environmental performance of the country.

However, the Global Innovation Index (GII), goes the other way around, since we can statistically infer this influence, demonstrating that innovation is indeed a part of the environmental performance of a country. This result can be found in table 3, where the GII influences approximately $65 \%$ of the results shown by the EPI. Therefore, we shall reinforce the previously described theoretical background of innovation, highlighting its influence on how paths may change in the environmental performance of the country. This logic is apparently related to the moment we live in contemporary society (Marques, 2018). Schumpeter's (1997) and Porter's (1999) ideas confirm the presupposition that innovation is a vital pillar of the national development process.

Our research findings follow and contribute to a path that is longly being constructed in the environmental literature. Senna, Campos and Silva (2017) are an example of this, as the authors highlight that innovation is a union of varied factors, which include firms, societies, and the government into a sphere that, in modern times, might contemplate enough technological resources to include environmental concepts in their reality. This prism might formulate a question in our minds: "Where does the government take place in this context?" Possibly, as a fostering agent, promoting a good environment with its policies, not only in the environmental field of study, but in the country as a whole - this justifies the high results regarding innovation that we could find in this paper. Also, according to Yu, Ramanathan and 
INDEPENDENT JOURNAL OF MANAGEMENT \& PRODUCTION (IJM\&P)

http://www.ijmp.jor.br

v. 12, n. 5, July-August 2021

ISSN: 2236-269X

DOI: 10.14807/ijmp.v12i5.1435

Nath (2017), these initiatives that come from the public or private sector can also assist at a national level, promoting sustainable development in the political and marketing contexts.

But we must, as a society, comprehend that innovation is a long-term process, however, when it is reached, sustainable economic development is also accrued (Insead, 2018). This comprehension promotes a necessary alignment, being also justified by Gill, Viswanathan \& Hassan (2018), while describing environmental issues as a gear that retains the economic growth through a Kuznet Environmental Curve. These same concerns must raise the awareness of national leaderships, avoiding major losses in the Gross Domestic Product of the nation, since it is clear that without a solid basis, innovation and development might change from a dream into a nightmare. Authors such as Mavragani, Nikolaou and Tsagarakis (2016) mention, at last, those international policies should obligatorily boost modern less favored countries, reinforcing social freedom, the welfare of the citizens, human rights of each individual, and mainly, the accomplishment of the true meaning of democracy by the state.

On the other hand, we should mention that the higher the human capital index (access to the available public structure such as health or education), the lower social inequality tends to be, among other factors. The Environmental Performance Index, since that human capital plays a crucial role in our social daily basis, showed itself as an indicator that deserves more attention and discussion by the state authorities, considering its relevance in regards to the available resources at the disposal of globalized and institutionalized nations.

We must also highlight that the already mentioned ecosystems are basic but crucial and unavoidable to the human condition since they offer various means of subsistence and survivability (Costanza et al.,2014), that is a good reason why a splendid environmental performance must be constantly sought. In addition, the innovation process also avoids or even minimizes environmental problems, as they also represent opportunities to reach competitive gains and sustainable growth among countries (Senna, Campos \& Silva, 2017). At last but not least, the governance approach, which deals with different political decision spheres, is also important, since in one way or another it frequently seeks a new level of quality in regard to the national policy results (World Bank, 2017).

\section{CLOSING REMARKS}

As a final discussion, we should reinforce the objectives of this study. We analyzed the influence of the Worldwide Governance Index and the Global Innovation Index on the Environmental Performance Index of 108 countries. This same performance shown by the countries reveals that the necessity of considering macroeconomic aspects exists and requires 
INDEPENDENT JOURNAL OF MANAGEMENT \& PRODUCTION (IJM\&P)

http://www.ijmp.jor.br

v. 12, n. 5, July-August 2021

ISSN: 2236-269X

DOI: 10.14807/ijmp.v12i5.1435

attention since they contribute in an overwhelming way to the environmental performance of nations. This context is aligned with the Theory of Institutions, and with the ecologic literature as well. Thus, we emphasize that good conduct in the macroeconomic policy-making process (which includes the Global GDP and Human Capital) is recommended, building a path towards a sustainable environmental performance and development of the nation.

Analyzing the alternative results, we may notice an absence of confidence and respect by societies with the democratic process - that means that the manner how these governments are elected and analyzed does not infer as a significant governance indicator in relation with environmental performance. However, as we have seen, innovation goes the other way around and it tends to constantly change the world we currently live in, inferring that these changes are also found in the environmental field, at least among the countries that are contemplated in the sample.

With that being said, governments must, again and again, act as a performer that pursues rational policies, and these deserve implementation at a national level. The results are logical, better performance in regard to environmental behavior is then expected. In relation to the control variables (Global GDP and Human Capital), they presented significance, indicating that other aspects - such as macroeconomic ones - go beyond the already known bias of innovation. This is the main contribution of this study, realizing that the environmental literature deserves to be expanded in a variety of ways, as well as the Theory of Institutions, which provided an imperative background to our research.

We also reiterate that governments and societies shall pay more attention and expand their knowledge in regards to this type of index, this improves the decision-making ability considerably, turning it into a more assertive mechanism, either it is in the public or private segments, remodeling the development of operations in a national level. In a nutshell, this study brings more clarification to the environmental field, opening paths for future researches in the area. One of our limitations, but also recommendations to future studies, is an expansion into these countries that were considered in our sample, analyzing whether activities that value the GDP of the country act as well with the environmental performance of the states, counties or geographical divisions, or if it perhaps does in an opposite direction.

\section{REFERENCES}

Arbix, G., Salerno, M., Toledo, D. G. C. D., Miranda, Z., \& Alvarez, R. R. (2010). Inovação: estratégias de sete países.

Bresser-Pereira, L. C. (2007). O modelo estrutural de governança pública. Revista eletrônica sobre a reforma do Estado, Salvador, (10), 2-19. 
Carvalho, C. A., Vieira, M. M. F., \& Goulart, S. (2005). A trajetória conservadora da teoria instituconal. Revista de administração pública, 39(4), 849-874.

Casady, C. B., Eriksson, K., Levitt, R. E., \& Scott, W. R. (2020). (Re) defining public-private partnerships (PPPs) in the new public governance (NPG) paradigm: an institutional maturity perspective. Public Management Review, 22(2), 161-183.

Chow, J., Kopp, R. J., \& Portney, P. R. (2003). Energy resources and global development. Science, 302(5650), 1528-1531.

Costanza, R., De Groot, R., Sutton, P., Van der Ploeg, S., Anderson, S. J., Kubiszewski, I., \& Turner, R. K. (2014). Changes in the global value of ecosystem services. Global environmental change, 26, 152-158.

Ezell, S. J., Nager, A., \& Atkinson, R. D. (2016). Contributors and detractors: ranking countries' impact on global innovation. Information Technology \& Innovation Foundation, January.

Fiorino, D. J. (2011). Explaining national environmental performance: approaches, evidence, and implications. Policy sciences, 44(4), 367.

Freeman, C. (1987). Technical innovation, diffusion, and long cycles of economic development. In The long-wave debate (pp. 295-309). Springer, Berlin, Heidelberg.

Freeman, C. (1989) Technology policy and economic performance. Great Britain: Pinter Publishers.

Freeman, C. (2002). Continental, national and sub-national innovation systemscomplementarity and economic growth. Research policy, 31(2), 191-211.

García-Álvarez, M. T., \& Moreno, B. (2018). Environmental performance assessment in the Eu: A Challenge for the sustainability. Journal of Cleaner Production.

doi:10.1016/j.jclepro.2018.08.284

Gill, AR, Viswanathan, KK e Hassan, S. (2018). A curva ambiental de Kuznets (EKC) e o problema ambiental do dia. Renewable and Sustainable Energy Reviews, 81, 1636-1642.

Gölgeci, I., Gligor, D. M., Tatoglu, E., \& Arda, O. A. (2019). A relational view of environmental performance: What role do environmental collaboration and cross-functional alignment play?. Journal of Business Research, 96, 35-46.

Grupp, H., \& Schubert, T. (2010). Review and new evidence on composite innovation indicators for evaluating national performance. Research Policy, 39(1), 67-78.

Hair, J. F., Black, W. C., Babin, B. J., Anderson, R. E., \& Tatham, R. L. (2009). Análise multivariada de dados. Bookman Editora.

Hoelscher, M., \& Schubert, J. (2015). Potential and problems of existing creativity and innovation indices. Creativity Research Journal, 27(1), 1-15.

Index, G. I. (2018). Energizing the world with innovation. Available on: https://www.wipo.int/edocs/pubdocs/en/wipo_pub_gii_2018.pdf. Accessed on: 17 abr.2020. Insead, W. (2018). Cornell University. (2018). The global innovation index.

Kaufmann, D., Kray, A., \& Mastruzzi, M. (2009). Governance matters VIII: Aggregate and individual governance indicators 1996-2008. The World Bank.

Kaufmann, D., Kray, A., \& Mastruzzi, M. (2011). Worldwide Governance Indicators 1996-2010. 
Kounetas, K., \& Zervopoulos, P. D. (2019). A cross-country evaluation of environmental performance: Is there a convergence-divergence pattern in technology gaps?. European Journal of Operational Research, 273(3), 1136-1148.

Lundvall, B. Å. (2007). Sistemas nacionais de inovação - conceito analítico e ferramenta de desenvolvimento. Indústria e inovação, 14 (1), 95-119.

Marques, L. (2018). Capitalismo e colapso ambiental. Editora da Unicamp.

Mavragani, A., Nikolaou, I. E., \& Tsagarakis, K. P. (2016). Open economy, institutional quality, and environmental performance: A macroeconomic approach. Sustainability, 8(7), 601.

Oecd, E. (2005). Oslo manual: Guidelines for collecting and interpreting innovation data. Paris 2005, Sp, 46.

Porter, M. E. (1999). Competição: estratégias competitivas essenciais. Gulf Professional Publishing.

Sampson, G. P. (Ed.). (2008). The WTO and global governance: future directions. UN.

Schumpeter, J. A. (1997). Ten great economists. Routledge.

Senna, P. P., de Campos, D. A. C., \& da Silva, G. R. (2017). Sistemas de Inovação Ambiental em Países em Desenvolvimento: uma discussão a partir do desenvolvimento do Etanol de Segunda Geração no Brasil. Pesquisa \& Debate. Revista do Programa de Estudos PósGraduados em Economia Política., 28(1 (51)).

Tecnologia e Inovação (Lei n. 13.243/2016). Economic Analysis of Law Review, 9(2), 308337.

Toigo, C. H., \& de Mattos, E. J. (2016). Desenvolvimento e meio ambiente: o que os principais índices têm a revelar?. Ensaios FEE, 37(2), 553-580.

Verde, L. H. L., \& de Resende Miranda, J. I. (2018). Uma análise econômica dos resultados brasileiros no Î́ndice Global de Eficiência em Inovação, frente ao novo Marco da Ciência.

Wendling, Z. A., Emerson, J. W., Esty, D. C., Levy, M. A., \& de Sherbinin, A., et al. (2018). 2018 Environmental Performance Index. New Haven, CT: Yale Center for Environmental Law \& Policy.

World Bank. (2017). World Bank country and lending groups.

Yong, G., \& Wenhao, C. (2012). Developing a city governance index: based on surveys in five major Chinese cities. Social indicators research, 109(2), 305-316.

Yu, W., Ramanathan, R., \& Nath, P. (2017). Environmental pressures and performance: An analysis of the roles of environmental innovation strategy and marketing

capability. Technological Forecasting and Social Change, 117, 160-169. 